\title{
The role of statutory and local rules in allocating water between large- and small-scale irrigators in an African river catchment $^{\dagger}$
}

\author{
Hans C Komakech ${ }^{1,3 *}$, Madison Condon², Pieter van der Zaag ${ }^{1,3}$ \\ ${ }_{1}$ UNESCO-IHE Institute for Water Education, Westvest 7, PO Box 3015, 2601 DA Delft, The Netherlands \\ ${ }^{2}$ Harvard University, 1563 Massachusetts Avenue, Cambridge, MA 02138, USA \\ ${ }^{3}$ Delft University of Technology, PO Box 5048, 2600 GA Delft, The Netherlands
}

\begin{abstract}
This paper presents a case study of large- and small-scale irrigators negotiating for access to water from Nduruma River in the Pangani River Basin, Tanzania. The paper shows that despite the existence of a formal statutory water permit system, all users need to conform to the existing local rules in order to secure access to water. The spatial geography of Nduruma is such that smallholder farmers are located upstream and downstream, while large-scale irrigators are in the midstream part of the sub-catchment. There is not enough water in the river to satisfy all demands. The majority of the smallholder farmers currently access water under local arrangements, but large-scale irrigators have obtained state-issued water use permits. To access water the estates adopt a variety of strategies: they try to claim water access by adhering to state water law; they engage with the downstream smallholder farmers and negotiate rotational allocation; and/or they band with downstream farmers to secure more water from upstream farmers. Estates that were successful in securing their water access were those that engaged with the local system and negotiated a fair rotational water-sharing arrangement. By adopting this strategy, the estates not only avoid conflict with the poor downstream farmers but also gain social reputation, increasing chances of cooperative behaviours from the farmers towards their hydraulic infrastructure investments. Cooperative behaviours by the estates may also be due to their dependence on local labour. We further find diverging perspectives on the implementation of the state water use permits - not only between the local and state forms of water governance, but also between the differing administrative levels of government. The local governments are more likely to spend their limited resources on 'keeping the peace' rather than on enforcing the water law. At the larger catchment scale, however, the anonymity between users makes it more difficult to initiate and maintain cooperative arrangements.
\end{abstract}

Keywords: water rights, legitimacy, conflict, subsistence irrigated agriculture, Tanzania

\section{Introduction}

Increased water scarcity leads to competition between water users, large and small, up- and downstream. Conflict may arise because upstream users abstract most of the water and leave their downstream neighbours with scarcity. To solve water allocation conflicts, many governments attempt to formalise the water rights system - users are granted rights to use a certain amount of water, at a particular location and duration. However, the formalisation of water rights may also provide opportunities for wealthier, more powerful, and better-connected users to manipulate registration to serve their own interests (Bruns, 2007). In addition, since sources of water rights are multiple and often conflicting, formalisation may lead to struggles over whose water right is legitimate. Smallholder farmers may base their water claims on customary rights and their historical investments in water infrastructure, while new users (e.g. large-scale irrigators and cities) use state-issued water rights to gain control of water sources.

\footnotetext{
An earlier version of this paper was presented at the CTA annual seminar - Closing the Knowledge Gap: Integrated Water Management for Sustainable Agriculture. Johannesburg, South Africa, 22-26 November 2010.

* To whom all correspondence should be addressed.

욜 +31 15 2151897; fax: +31 15 2122921; e-mail: h.komakech@unesco-ihe.org Received 10 February 2011; accepted in revised form 14 December 2011.
}

This paper presents the struggles for water access and control in Nduruma River, upper Pangani River Basin, Tanzania. The present water rights system in Tanzania builds on water law established by the colonial authorities in the early 20th century - a law specifically designed to limit use among native inhabitants while at the same time securing access to water for European settlers (Lein and Tagseth, 2009). In addition to the colonial-induced water access asymmetry, more recent increased water demand has led to fierce competition in the Nduruma sub-catchment. This increasing water demand is partly caused by the revitalization of coffee estates by both local and international private capital. Several of these estates are relics of the German and British colonisers (cf. Spear, 1997). Most of the coffee estates have been converted into large flower farms by a new group of white farmers, making the present social-geography a mirror image of the colonial past. The area which was once called the 'iron ring of alienated land' (Spear, 1997), is called today the 'plastic valley' because of its numerous greenhouses. Old estates were also the centre of the protracted struggles over water and land resources between the local people (Meru and Arusha), white settlers, and the colonial administration (Spear, 1997). Just as in the colonial time, present-day water users relying on Nduruma River must operate in a plural legal context that is made up of locally-evolved water-sharing practices and the water rights system crafted by the national government.

This paper illustrates how new commercial estate owners (mostly international companies) in this sub-catchment must 
adapt to local concepts of legitimate water rights to survive. They must accept the fact that acquiring state water rights does not automatically translate into legitimacy at the local level. To understand the dynamic of the struggles for water rights in the sub-catchment we develop a conceptual framework based on Boelens echelons of water rights analysis (Boelens, 2008; Zwarteveen et al., 2005) and the concept of legitimacy (Bodansky, 1999; 2007).

It is important at this point to clarify our use and preference for the terminology of institutions - informal, formal, customary, modern, indigenous, local, bureaucratic and stateled. Similarly to Komakech et al. (2011), we use the term local to mean farmer-initiated water allocation rules that evolved over time. We prefer the term 'local' over the commonly used 'informal', because access and use of irrigation canals is often strongly regulated and enforced and combines both customary and modern elements. Similarly, we use 'statutory' to signify government-sanctioned water management rules. We put particular emphasis on the origin of the rules instead of stating their perceived false formality or modernity (see Komakech et al., 2011). Formal rules may also have informal origins and calling them modern wrongly suggests that they are better than traditional institutions.

The paper is organised as follows: The conceptual framework used to explore water rights struggles in the Nduruma sub-catchment is followed by a description of the case study catchment. The water governance context in the Nduruma subcatchment is discussed, after which cases of rights struggles and negotiation processes are presented, focusing on the role of large-scale irrigators in local water allocation systems. This is followed by a discussion of the research findings in light of water rights theory and formalisation. Finally, by way of conclusion, some lessons for the development of catchment water allocation systems are provided.

\section{Framework: water rights, struggles and control}

Property rights define an individual's rights, privileges and associated limitations of a specific resource use; allocation of property rights affects the efficiency of resource use (Schlager and Ostrom, 1992). According to Bromley (1997), property provides some benefit streams, while a right to property offers security over that benefit stream. A property right defines a relationship between individuals (or groups) with respect to the use of a particular resource and the benefits this use generates. To have a property right is to have the capacity to require some authority system to defend your interest against the interests of others (Bromley, 1997: 50). Because of its vital, rivalry and non-excludability characteristics, water is a unique resource, the management of which requires a suitable set of institutional arrangements. A water right is therefore often composed of a set or 'bundle' of graduated privileges that are assigned to different social entities (Bruns, 2007; Schlager and Ostrom, 1992; Shi, 2006). This defines who is entitled to a certain amount of water, at a particular time and location, during scarcity.

The sources of water rights are multiple and dynamic. They often take many forms at many levels of water management. Water allocation is not necessarily a matter of formal licences to abstract water or contractual commitments for water delivery, but also local understandings such as taking turns to use water, and when and where irrigation water may be used (Bruns, 2007). According to Bruns (2007), real access to water depends on how water is allocated at multiple levels, among larger jurisdictions such as nations, states, provinces, and districts and among organisations and individuals extracting water from rivers and aquifers, as well as on the crucial details of water distribution within irrigation systems. Water rights may be implicit in the design of structures, and asserted in decisions about guarding, maintaining, or modifying irrigation infrastructure (Bruns, 2007; Lankford and Beale, 2007). Even when water rights are formally stipulated, such entitlements must still be translated into seasonal and daily decisions about withdrawing water.

With increasing water scarcity, most governments find themselves walking a tight line. To create, maintain or restore order, governments assert full ownership of water, and, in theory, also the sole authority to determine who is entitled to water at a particular point in time (Bruns and Meinzen-Dick, 2001; Molle, 2004). Water users (individual or groups) are granted 'official' licences or permits to use a certain amount of water, at a particular location and duration. Domestic users may be granted access to water (mainly for drinking) without a permit. The duration of rights may be permanent, for a number of years, or made conditional upon productive use, but does not usually take into account hydrological variability (Molle, 2004). Common belief is that the state's prescriptive water right is legitimate and legal. However, alongside the statutory rights system are local norms and customs that mediate day-to-day access to water.

By contrast, local water rights (based on customs and norms), are locally developed and adapted through step-by-step negotiation between the users - often building on a pre-existing rights system. As described by Molle (2004), the process of negotiation occurs at several nested levels in a river basin:

- At the river level, during dry seasons there may be insufficient flow to meet all demands and this gives way to negotiated rules for sharing between user groups (e.g., irrigation canals using one river), and they are constantly redefined.

- Within an irrigation canal, users' participation in maintenance may be instrumental in the definition of allocation rules in case supply is unable to meet demand.

Locally-negotiated water rights are often sanctioned by the authority vested in the decision-making body (e.g. river committees) and by the social recognition of these structures. Also of importance is the fact that at the level of an irrigation canal, water rights are often tied to labour investment in the hydraulic property which enhances one's claim to water access (Coward, 1986).

Water rights claims are often contested. As depicted in Fig. 1, the struggle includes competition over who gets access to water, infrastructure and material means (resources); contest over the formulation and contents of water rights and operational norms (rules); struggle over decision-making authority and the legitimacy of rights systems (regulatory control); and the diverging discourses that defend or challenge particular water policies, normative constructs and water hierarchies (regimes of representation) (Boelens, 2008).

The 4 components are involved simultaneously and chained together in particular ways, establishing how water is distributed, how humans and non-humans are ordered in socio-technical hierarchies, how this is legitimated by moral and symbolic order, etc. (Boelens, 2008; Mehta, 2007). Such alignments take place in ways that either strengthen or challenge the status quo. In this way, water rights struggles are at the centre of power relations. Power is used here to mean relational effects arising out of one's location advantage, access to other material resources and/or psychological strength (Piccione and Razin, 


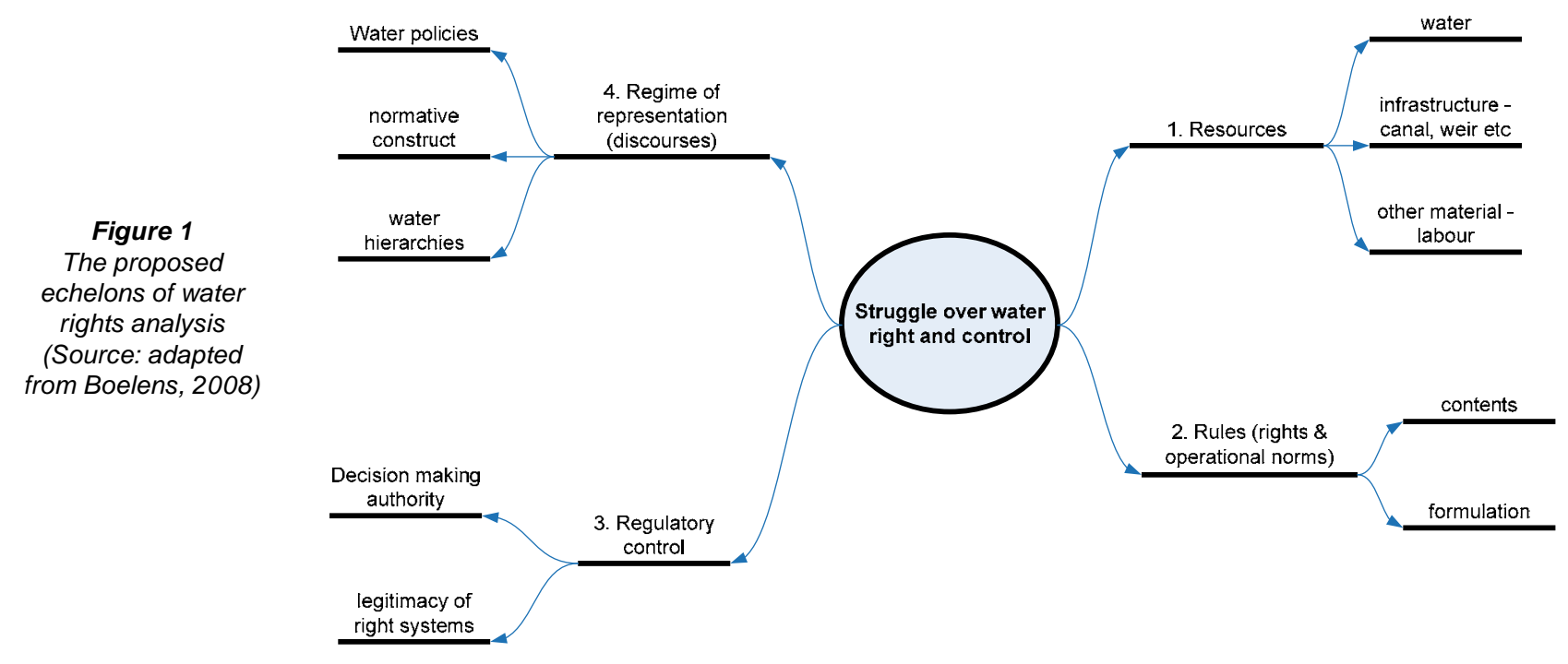

2009). Power relations generate key features of water rights content, distribution and legitimacy, and, in turn, water rights in action reproduce or restructure power relations (Boelens, 2008). For instance, acts of resistance against a dominant actor (e.g. attacks on estates intakes) may subvert power relations between the actors and this in turns affect water control.

In sum, water rights stand at the centre of struggles over legitimacy. Legitimacy describes the formal and informal ways in which processes, policies, structures and agents are validated and consequently empowered (Gearey and Jeffrey, 2006). The challenge is in equating legitimacy to legality. Legitimacy has both a normative quality and a social dimension - it is not only a reason for action but also the justification for action (Bodansky, 2007; Gearey and Jeffrey, 2006). Bodansky (2007) argues that legitimacy is a much broader concept than legality in at least 3 ways: (1) legality is one possible justification of authority, but not the only criterion in assessing authority of institutions (e.g., a certain use of water may be illegal yet considered legitimate by some); (2) exercise of authority can exist outside a legal system and still raise issues of legitimacy (e.g. traditional leaders); and (3) legitimacy relates not simply to compliance, but to the justification of authority more generally. He argues further that an institution may be considered legitimate when users think that it serves their self-interest. We use the above conceptualisation of water rights struggles to explore the dynamic of water access and distribution between large-scale irrigators and smallholder farmers in the Nduruma sub-catchment.

The complex nature of accessing water can be aptly illustrated by the case of Nduruma River. In this catchment small and large-scale irrigators mediate their differing perspectives because they share one and the same source of water.

\section{Research methods and case study sub-catchment}

\section{Research methods}

The objectives of this research were to describe and analyse water-sharing agreements among and between various users of the Nduruma River. We were particularly interested in how each user's unique situation affected water use and cooperation with other users. Our consideration of situation included questions of: location (upstream or downstream); political influence; size of demand and/or production; type of intake and/or irrigation technology employed; and whether the user was foreign or local. To achieve these objectives, we first needed to identify all users, their location, and intake points. To identify the users and their networks, we followed the Nduruma River downstream, mapped the hydraulic infrastructures tapping the water source (predominantly irrigation canals referred to here as furrows), and followed them back to their owners.

Once each furrow was located and attributed to either a village or an estate, we conducted interviews with various stakeholders and irrigation committees. We started group interviews with village furrow committees: 7 members, including the village chairmen, each from Makasuro sub-village, Nduruma, Moivaro and Madawe villages; and 14 members from Manyire village. Discussions with these groups were conducted around a similar set of questions to determine current norms in use, how water is allocated to each furrow, and how this is transformed into water access for individual members of a furrow. We also investigated what the village leaders thought about how their water use influenced downstream users, and how their supply was affected by those upstream.

We also met with at least one representative from each of the estates located in the mid-zone of the Nduruma River: the owner of Old River Farm; the former owner of Gomba Estate; the farm manager of Dekker Bruins; the director and irrigation manager of Arusha Blooms; and the environmental and fertigation officers of Kiliflora. Questions asked of these individuals were similar to those asked of the villagers, such as determining if their water supply met their demand and how they affected and/or were affected by surrounding village users. In addition, representatives were asked to describe their relationship with surrounding villagers and their strategies to secure access to water.

Interviews were also conducted with officials from the local governments and basin authority to get a broader understanding of the issue: the Meru District Irrigation Officer; the Water Officer at the Pangani Basin Water Office; the Nduruma Ward Executive Officer; and the Sokon II Ward Office Chairman. We asked them to describe the current state of water sharing (or conflict) and how state-issued water rights were influencing the situation.

For those villages that had River Committees in place, we met and conducted interviews with the committees' head members as well. We held discussions with the chairman and 


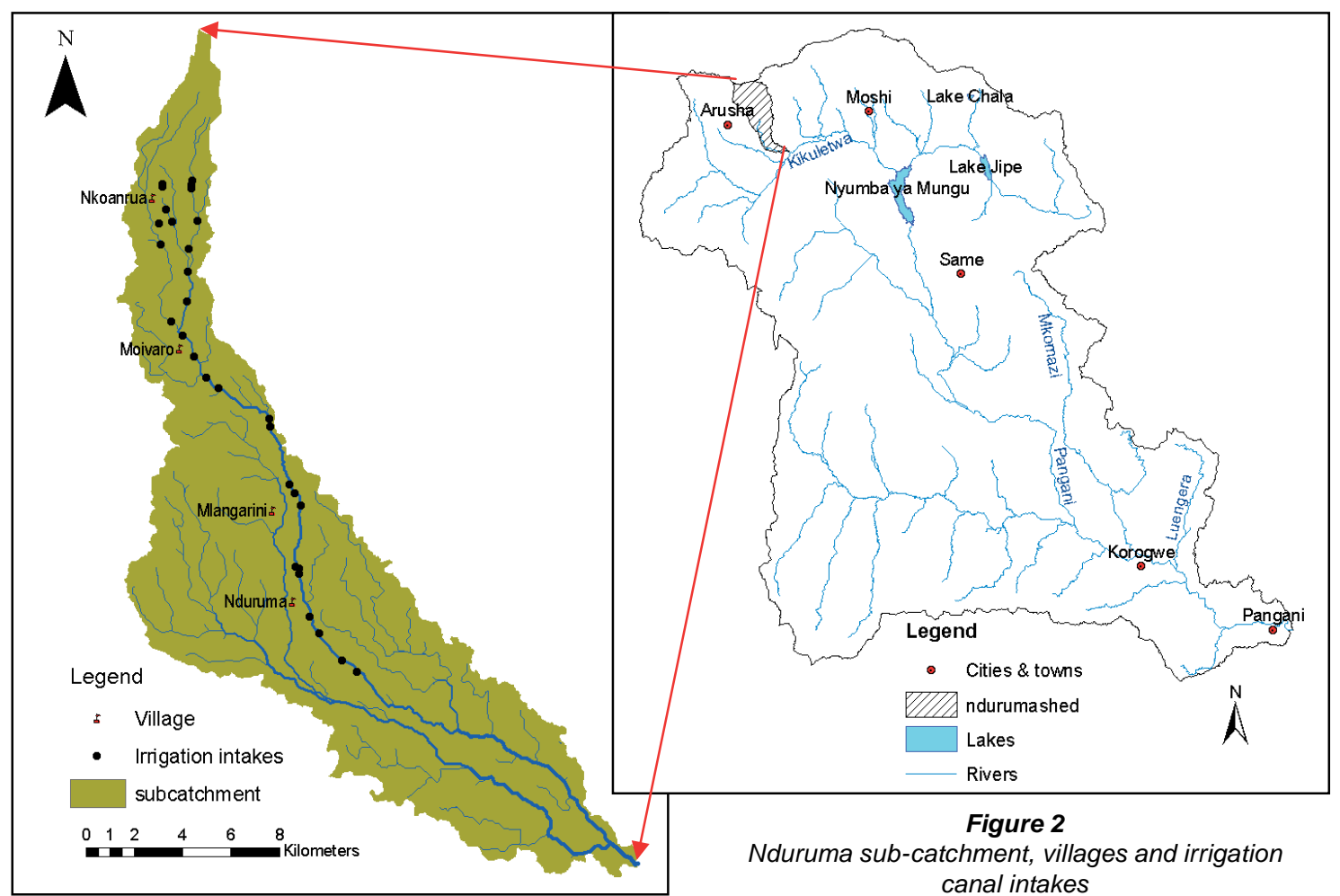

\begin{tabular}{|l|c|c|l|}
\hline \multicolumn{3}{|c|}{ Agro-ecological zones of Nduruma sub-catchment } \\
\hline Zone \& wards & $\begin{array}{c}\text { Elevation } \\
\text { (AMSL*) }\end{array}$ & $\begin{array}{c}\text { Rainfall } \\
\text { (mm/yr) }\end{array}$ & Land use/dominant features \\
\hline Forest reserve & Above $1800 \mathrm{~m}$ & $\sim 1400$ & Forest reserve, wildlife, lumbering, mining. National park \\
\hline Highland & $1400-1800 \mathrm{~m}$ & $\sim 1000$ & $\begin{array}{l}\text { Subsistence agriculture (major crops: coffee, bananas, sugarcane, yams, maize, } \\
\text { vegetables, and sweet potatoes). Supplemental irrigation practiced but changes } \\
\text { to full irrigation during dry seasons. Livestock are stalled - mainly dairy cattle. } \\
\text { Water used for domestic, irrigation, livestock and Arusha municipal supply }\end{array}$ \\
\hline Midland & $1000-1400 \mathrm{~m}$ & $\sim 500$ & $\begin{array}{l}\text { Referred to as "Plastic Valley," the area is under intensive agriculture. Crops } \\
\text { include coffee, banana, maize, beans, horticultural crops and export flowers. } \\
\text { Originally white settlers' coffee estates but now changing into larger commer- } \\
\text { cial flower growers (majority international investors). Competition over water is } \\
\text { intense. }\end{array}$ \\
\hline Lowland & Below $800 \mathrm{~m}$ & $\sim 400$ & $\begin{array}{l}\text { Subsistence agriculture and livestock. Receives low rainfall, highly affected by } \\
\text { upstream water use. Major crops: tobacco, rice, beans, maize, and vegetables. } \\
\text { Livestock are free-range, mainly own by pastoral Maasai. }\end{array}$ \\
\hline
\end{tabular}

secretary of the Nduruma and Manyire River Committees. The committee members were asked to give their own perspective on the questions listed above. In addition, they were asked general questions about the committee itself: why it was formed and whose idea or initiative it was, how a furrow group can become a member of the River Committee, the specific role of this committee, especially with respect to water allocation, its spatial span of control, management structure and election of representatives and leaders, and its relationship with estates and estate managers.

\section{Nduruma River}

The Nduruma River, located in the upper parts of the Pangani River Basin, originates in a protected forest reserve near the summit of Mount Meru and is fed by small tributaries (Songota and Manyire being the main ones) and springs along its course (Fig. 2). Rainfall is bimodal with short rains (vuli) from November to January and long rains (masika) falling from March to June.

Eight administrative wards of the Arumeru district depend at least in part on the Nduruma River at some time in the year: Bangata, Nkoanrua, Sokon II, Mlangarini, Nduruma, Moshono, Kikwe, and Mbuguni. These wards can be divided into 3 groups based roughly on altitude and composition of the water users - highlands, midlands, and lowlands (Table 1).

The highlands begin below the forest reserve and end just above the Arusha-Moshi highway. Irrigation has been practiced for more than 200 years in the highland zone. The villages in this zone are Midawe, Bangata, and Nkoanrua. The western bank of the river is mainly occupied by Arusha people and the eastern bank by the Meru people (Spear, 1997). The main source of income for this area is the cultivation of maize and bananas, coffee, pyrethrum and round potatoes. The most upstream village of Midawe has several furrows that in fact draw from springs and the river Songota, a tributary of Nduruma. Off the Nduruma River itself, there are 4 main 


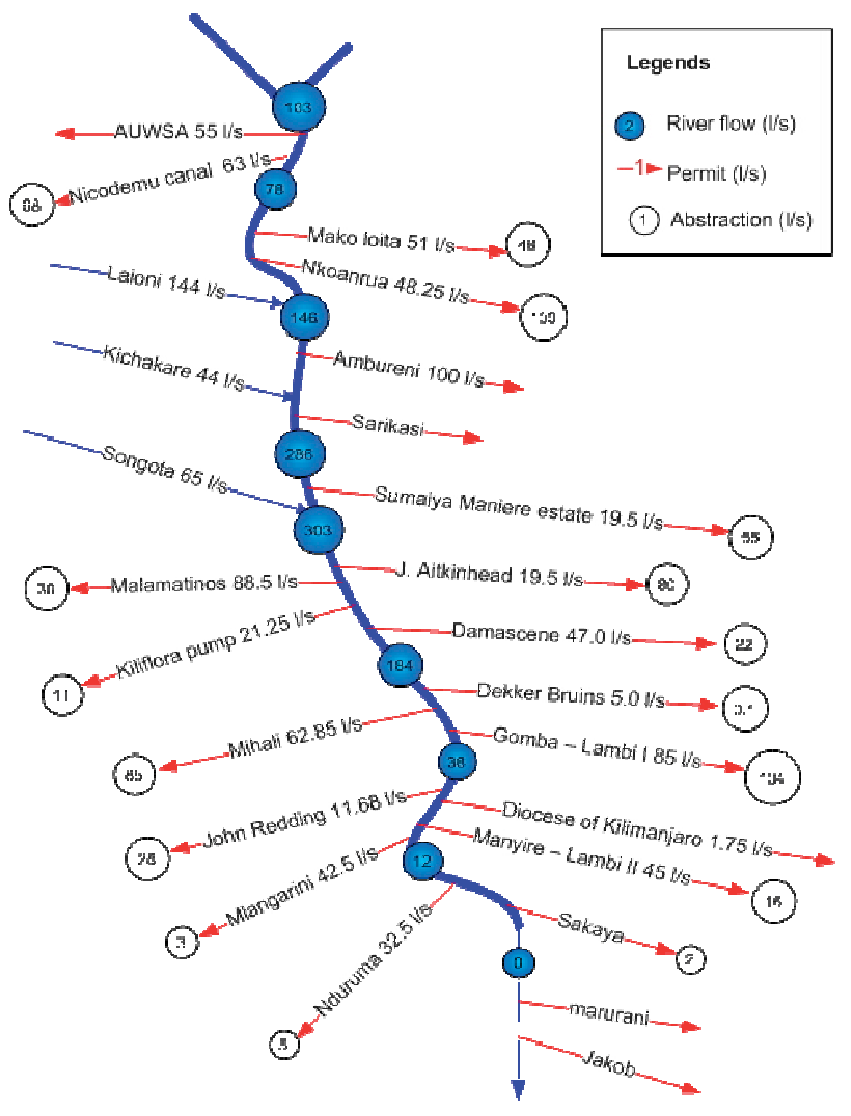

Figure 3

Existing water use structures with and without state-issued water rights in Nduruma River and their measured dry season water abstractions, November 2003. (Source: PBWO archive)

furrows. Due to the large population, there is a large shortage of land in this zone, and this leads to degradation of the water sources and river banks, as people are forced to farm any available land.

The midland zone is roughly defined by the current Arusha-Moshi highway and the Old Arusha -Moshi dirt road. It overlaps with the area that locals call the 'plastic-valley' because of the huge number of (plastic-roofed) greenhouses, belonging to commercial farmers, which dot the landscape. Formerly, the area was used for coffee production and formed what Spear (1997) called the 'iron ring of land alienation' around the base of Mount Meru. The coffee estates around Mount Meru were not nationalised by the independent government of Tanzania (Baffes, 2003; Spear, 1997). These estates are foreign-owned and depend on Nduruma River for intensive irrigation to grow flowers and vegetable seeds needed for the international market. Smallholder farmers are the minority in the midlands, both in terms of their number and their landholdings. Manyire tributary originates from this zone and is being used by the estates and surrounding villages.

The lowland zone of the Nduruma valley is semi-arid. Until recently, the area was used for commercial sisal production and livestock grazing. Currently, the main economic activities include livestock keeping and subsistence agriculture. The majority of users are smallholder farmers who predominantly grow maize, beans, rice, tomatoes, vegetables and fruits. Some of the villages farthest downstream have been recently populated by people moving from different parts of the country. The most upstream portion of this zone also overlaps with the 'plastic valley', and thus there is a fair number of large-scale irrigators here as well, clustered just below the Old Arusha-Moshi road. The villages in this zone relying on Nduruma water are Mlangarini, Manyire, Mzimuni, Marurani, and Nduruma.

\section{Water governance in Nduruma}

Irrigation along the Nduruma River dates back more than 200 years (Spear, 1997), but intensive water use only started to pick up pace during the colonial period, when white commercial farmers settled in the area, and began using the same water resources as the indigenous population. A map dating back to 1959 provides an illustration of the land use situation shortly before independence. This map was obtained from Pamoja archives and was made by 'J.N.S.' on 10 April 1959. Only the initials of the author are indicated, and we suspect that the map was made through a directive from the colonial administration (see Spear, 1997). The majority of the furrows are in the highlands, and are labelled 'African.' Below them, in the midland, there are fewer, but longer furrows, the majority of which are labelled 'European.' Below these (lowland), only a small number of short furrows can be seen, which are once again labelled 'African.' The situation is not much different today; the present geography is such that smallholder farmers are located upstream and downstream while the midstream zone is mainly occupied by large-scale irrigators growing flowers for European markets. This spatial geography shapes the nature of water governance in the catchment. This section briefly describes, first, the state-sanctioned water right governance system in Nduruma River; second, the local water governance arrangements; and third, the functioning of the locally-developed Nduruma River Committee.

\section{State-sanctioned water right governance in Nduruma}

The German and British colonisers first introduced statutory water law in what is now mainland Tanzania in the early $20^{\text {th }}$ century; all water was declared a state resource and the water right permit system was introduced (Lein and Tagseth, 2009; Maganga, 2003). The water rights system was particularly introduced to curtail natives' water use and secure water for white commercial settlers who had interest in agricultural intensification in the highlands (see Komakech et al., 2011). In the Nduruma sub-catchment, local farmers were dispossessed of their lands and water resources (Spear, 1997). Subsequent amendments have since been made to the Water Utilization (Control and Regulation) Act in 1948, 1959, 1974, 1981, 1996, 1997 and 2009. A volumetric water use fee was first introduced in the 1974 Water Utilization (Control and Regulation) Act. The Tanzanian government recently reformed its water sector: in 2002 a new National Water Policy was put in place (United Republic of Tanzania, 2002). Under this policy, water belongs to the state, and all water users with an intention to abstract surface or underground water must acquire water rights from a designated basin water authority (basin water board/office). However, with the exception of volumetric water use fees, the current water rights system is still similar in many aspects to the colonial water law. A basin water board may grant or refuse water rights to any person or groups. If granted, the water right specifies the purpose, volumetric amount allowed, duration of the right, and the source (United Republic of Tanzania, 2009). A permit holder may, with the consent of the basin water board, temporarily lease his/her use right to anyone, and for 
any duration, provided that the duration of the permit is not exceeded. Nothing in any water use permit granted implies any guarantee that the quality and quantity of water referred to is, or shall be, available. Permits may be declared by the basin board as appurtenant to land described in the permit. However, state-issued water rights seem to lead to over-abstraction in many places. In the Rufiji basin, for example, issuing water rights led to over-abstraction and increased competition as users argued that acquiring a state water right is synonymous with owning the water (see Van Koppen et al., 2007). The problem is that 'water rights' was translated to Swahili as haki za kumiliki maji (water property rights) - which made users think that acquiring a permit conferred full ownership rights. The government tried to address this problem with the new Water Act (Control and Regulation 2009) by redefining the phrase 'water use permit', using the Swahili haki ya kutumia maji (right to use water). In addition current water use permits are issued to users specifying a fixed flow rate, determined based on the assumption that an average supply exists (Lankford and Beale, 2007; Van Koppen et al., 2007). However, in the Pangani and other basins in Tanzania rainfall and hence water supply is highly variable, which makes the state allocation inappropriate, especially during low flows (dry seasons or during droughts).

The Pangani Basin Water Board (PBWO), through its executive basin office, is responsible for allocating all water rights in the basin of which Nduruma is a sub-catchment. PBWO maintains a database of all users in the basin and handles all new requests. Most of the large-scale irrigators along Nduruma acquired their water rights during the colonial time, but these were revised by PBWO in 2003 to accommodate Arusha City's water demand (Komakech et al., 2010). Figure 3 is a sketch of water right status and measured dry season abstractions along Nduruma River.

Through their system of indirect rule, the British also created the conditions for a pluralist system of water governance in Tanzania (Spear, 1997). They created Crown Land to be governed by statutory law and Native Reserves (land occupied by the Africans) to be governed by local law. Ever since the colonial time, customary rights in the Pangani River Basin have coevolved with statutory water rights.

\section{Local water governance in Nduruma sub-catchment}

The furrows in the highlands each have a committee, composed of a chairman, secretary, and members. For most of the furrow committees there is also a 'council' of elders who act as advisors. The committees are mostly concerned with organising the youth of the community into a maintenance schedule for the infrastructure. The furrow committees generally meet every 3 months and elections for membership are held every 4 years, at the annual village committee meetings. In the dry season, when water is scarcer, there is a need to precisely allocate the water amongst the various farmers (via a rotational system). Most of the highland furrows drawing from the main stem of the Nduruma River have metal intake gates, but furrows drawing from springs and Songota tributary have no lockable gates. However, all metal gates were found locked in the fully opened position, or intentionally destroyed in order to abstract more water, a sign that they are not used to regulate water allocation. All highland furrows abstract water simultaneously with no turn-taking enforced even during the dry season.

Highland furrow committees claimed that there is no conflict amongst the villages themselves. Although some downstream villages use these same furrows the highland furrow committees never organise meetings with them. Nkoanrua's furrow chairman explained that the reason why they have never met with downstream users such as Moivaro Village is because these villages tap springs which ensure domestic water supply. Because of this domestic supply, downstream villagers are believed to receive enough water to survive. The highlanders do not seem to bother whether or not the downstream villagers receive enough water to produce sufficient food and maintain their livelihoods.

In the midland area, only furrows used by smallholder farmers have committees with structures similar to those of the highlands. Large-scale irrigators do not use committees to manage their furrows. During the rainy season, farmers in Moivaro, for instance, claim that they don't irrigate so they only use intra-village allocation schedules in the dry season. In May and June, the furrow committee is in charge of repairing the furrows that were damaged, in preparation for the coming dry season. The furrows are typically silted up during the rains and the intakes get damaged. There is an annual fee of around 2000 to 3000 Tsh (1.34 - 2.00 USD) collected from each plot (shamba) in the village for completing the furrow repairs.

Lowland furrows have committees with the following composition: 3 water distributors, 3 advisors, 2 water guards, a chairman, treasurer, and secretary. These committees are responsible for water allocation to individual farmers, routine maintenance, and resolving resource conflict. The chairman, secretary, and advisors determine the day-to-day water allocation schedule. Individuals are assigned water for approximately 2 hours each. Despite this planning, villagers still steal water along the way. There is a 5000 Tsh (3.34 USD) fine for water theft, which is handled within the village government system.

\section{Local catchment wide governance structure: Nduruma River Committee}

There is no overall water management institution for the Nduruma sub-catchment that is recognised by the Pangani Basin Water Board. This notwithstanding, the allocation of water between the midlands (mainly large-scale farmers) and lowlands is being managed by the Nduruma River Committee. The villages that actively participate in the River Committee are Mlangarini, Manyire, Mzimuni, Marurani, and Nduruma. According to the current Board Chairman, in the past there was sufficient water, but during droughts or dry seasons, elders would meet and agree on allocation schedules. There was one elder whose role was to guard the river. He would follow the river upstream and negotiate with upstream farmers. Between 1962 and 1974, an extreme drought occurred and the idea of the committee emerged. Leaders of the individual furrows would meet after examining the levels of available water in the Nduruma River and then agree on allocation schedules. However, the discussion of allocation schedules in 'traditional' times never travelled beyond Ambureni/Moivaro Village to the highlands. The Nduruma River Committee in its current structure was initiated in 1999 by smallholder and large commercial farmers with the support of the Arumeru District Commissioner. This is also the year when the first formal elections occurred for the chairman and secretary.

Currently, every furrow in the mid- and lowlands is represented on the Nduruma River Committee, normally by the chairman and secretary of the furrow. Within each furrow there is an election every 3 years for these positions. If there is a problem, new members are selected to replace old ones. 
Among these representatives, a chairman and a secretary of the Board are elected. In addition, the security guards from each of the furrows attend the Board meetings, but do not vote. Representatives from each of the estates attend committee meetings as well - normally the estate farm managers or irrigation officers, who are always native Tanzanians. The current chairman of the River Committee is from Mlangarini Village and the secretary from Nduruma Village.

The Nduruma River Committee is responsible for setting the allocation schedules for each of the main villages as well as commercial estate furrows. If it is discovered that a furrow/ estate is violating the agreement and abstracting outside of its allowed time, the Board levies a fine on the responsible party. In the case of the estates, the fine is levied in the name of the estate representative to the Board, usually the irrigation manager. Stephen Gregory from Tanzania Flowers explained that in his case the estate would cover the penalty. In the case of the village furrows, the fine is levied against the furrow chairman regardless of who made the irrigation offence.

Under local water-use bylaws, the punishment for stealing water was to supply a sheep or goat to be eaten by the clan. Since 1999 the fine has been levied in Tanzania shillings. The fine for estates was raised in January 2009 from 100000 Tsh to 200000 Tsh (67-134 USD). The fine for village farmers caught stealing is variable and usually a much smaller sum. This punishment is often relegated to the individual furrow committee to manage. In theory, if a villager is unable to pay his fine he is expected to forfeit a section of his land, but in practice this has never occurred.

There are no registration or membership fees for being a part of the River Committee. Most of the large estates make voluntary payments when asked. These cash allotments go toward small purchases such as refreshments for meetings. The River Committee has no bank account and thus no mechanism for storing large amounts of money. Nelson, from Dekker Bruin expressed his frustration concerning this matter: 'Sometimes [the estates] are sent a request for funds, or someone asks for [help with] transport to the [meetings]. The Board should really have an account. There are silly problems like sometimes the chairman fails to phone because he has run out of credit.' Because the requests for financial support are informal and sporadic, estates have no way of knowing if they are sharing the financial burden. It is apparent that Tanzania Flowers and Dekker Bruins have borne the brunt of the costs. The Nduruma River Committee has no headquarters or office and meetings are generally held in an open field on the property of Dekker Bruins.

Finally, Manyire villagers claim that they have a River Committee for Manyire river. The committee reportedly was elected in the year 2000 during a general assembly attended by the villages of Manyire, Maji moto, Karangai and Makasoru. Apparently Nambala and Kikwe village were not part of the meeting. Nambala village is in conflict with the other villages and does not recognise Manyire River Committee.

\section{Legitimacy and struggles over water access and control}

The situation in Nduruma is challenging for the large-scale irrigators who want to invest in an environment where the state's water law is deemed legal and legitimate at all levels. All largescale irrigators in the sub-catchment have state-issued water rights (also referred to as 'official' water rights). Although some smallholder groups have also acquired state water rights on their irrigation canals, the allocation of water 'on the ground' is being done according to local rules. This leads to struggles between the smallholder farmers, who appeal to customary principles and the large-scale irrigators, who want to adhere to the state's statutory water law. In addition to the struggle over water access and control, the large-scale irrigators also invest in water-related infrastructure to secure access to water. The technological innovations include the use of a 'high-tech' drip irrigation system, rainwater harvesting from the greenhouse roofs, storage infrastructure and boreholes. We present in this section 3 cases of conflict and cooperation between the estates and smallholder farmers: first, Gomba Estate that claims that only the official legal right is legitimate; second, Enza Zaden that attempts to mediate conflict between Manyire users; and third, a group of estates that agrees on rotational allocation with smallholder farmers.

\section{Contested official water law: case of Gomba estate}

One notorious example of conflict between the Nduruma River Committee and a foreign-owned commercial farm is the case of Gomba Estate. In 1996, a Canadian investor took over a failed coffee estate in the midlands. The old coffee estate had 2 permanent water rights attached to the land: one water right is from Nduruma River (issued for Lambi 2 Furrow) and another from nearby Manyire River (issued for Lambi 1 Furrow). Lambi 2 was already being used by the village of Manyire. Gomba Estate embarked upon a large operation to grow a diversity of crops - mainly vegetables and fruit trees. The downstream villages of Manyire, Nduruma, and Mlangarini immediately noticed the decrease in dry-season water supply when the farm became operational.

On behalf of the downstream villagers, the Nduruma River Committee attempted to meet with the Canadian to negotiate a water-rationing schedule. According to the village leaders of Manyire and Nduruma, 'He wouldn't attend any of the meetings to discuss water allocation. We tried to levy fines on him for taking water at the wrong time but he refused to pay and wouldn't let us in at the gate [of the estate].' The Canadian's reason for refusing to negotiate with the Nduruma Board was that he felt he had an 'official' legal right to the amount he had been allocated by Pangani Basin Water Board/Office (PBWO) and for which he paid an annual fee. He also felt uncomfortable establishing agreements with an unofficial organisation when it concerned the success of his estate. Explains the Canadian, 'What you end up with are guards with machetes watching your water intake to make sure you don't open it too early. No one knows what is official or not. Inside the villages the villagers themselves steal the water - it is impossible to negotiate with that many people at once.'

For support of his claim, the Canadian called the District Commissioner and cited his official water right. In his words, 'All I would ask was, "Please apply the law."” Village leaders from Nduruma interpreted this behaviour as disrespectful and unaccommodating. The Canadian refused to solve anything without first calling the area Ward Councillor (Diwani). In the words of the village chairman of Nduruma, 'The Canadian only knows 3 people: the area member of Parliament, the President, and the Minister of Investment. He was very rude; he wouldn’t attend the River Committee meetings.' In response to the Canadian's refusal to negotiate, many of the villagers responded with violence. Gomba's furrow intakes were vandalised and its irrigation workers were harassed. According to the Canadian, these were common occurrences during the dry 
season, 'There were literally mobs of people with machetes at the intake from June to the end of February the following year.' Gomba Estate stopped operation in 2007. The land of the estate now lies abandoned, but Manyire village regained control of Lambi 2 Furrow.

\section{Mediating local conflict: Enza Zaden's role in Manyire water conflict}

Enza Zaden is a Dutch-owned vegetable-seed breeding estate located along the Old Arusha-Moshi Road. In 2005, the company bought 45 acres of land that was once a coffee plantation known as Sarkos's Farm. Although the estate has water rights to use both the Nduruma and Manyire Rivers, it doesn't take any water from them because in the dry season there is not sufficient water. Instead, the main supply comes from a borehole near Lake Duluti, $1 \mathrm{~km}$ upstream of the estate. This borehole has been registered with PBWO, for which the estate pays an annual fee. The estate has also drilled a second borehole for reasons of water security and claims to be in the process of registering it with PBWO. Enza employs 140 people on a permanent basis with an additional 40 temporarily hired to assist with the ongoing constructions on the farm. Almost all of these employees come from the downstream villages of Manyire and Nambala.

In early 2001 Nambala Village dug a new furrow from the Manyire River across the land now owned by Enza Zaden. At the time there was no agricultural activity taking place on this land. The furrow is called SANAKIMA, an acronym derived from the names of its users: Sarkos's Farm, Nambala Village, Kikwe Village, and Maweni Village. Representatives from Nambala explained that this furrow was necessary because their main water source, the Ganana River, had dried up from overuse upstream. Nambala and Kikwe also claim to have been drawing water from Manyire River since 1978, at which time there were unofficial user agreements between the various village heads.

Downstream of Enza's estate and the SANAKIMA intake are the villages of Manyire, Karangai, and Maji Moto, with a total of 16 furrows which use the Manyire River as their source. The 7 furrows that support Manyire Village are: Majengo Juu, Majengo Kati, Mshikamano, King’ori, Kusini A, Kusini B, Levorosi, and Upendo. According to the chairman of the Manyire River Committee, representatives of the Board complained to PBWO about the construction of SANAKIMA furrow. He claims that PBWO, which does officially recognise the aforementioned 7 furrows, ordered the closing of SANAKIMA. Meanwhile, Nambala's village committee claims that they are in the process of registering for an official water right with PBWO. A tenuous sharing agreement was agreed between the 2 parties concerning the times of opening and closing of the SANAKIMA furrow. However, there continued to be many disagreements between the members of the villagers - each side of the argument sent a full-time watchman to guard the furrow intake point on Enza Zaden's property. On several occasions there were violent interactions involving machetes when one village accused another of either opening or closing the furrow at inappropriate times. The intake of SANAKIMA furrow was not fitted with cement lining or a control gate. This meant that water flow was controlled by the infilling of stones and soil excavated from the riverbank and from the nearby Enza Zaden farmland - a routine activity that contributed to the degradation of the source and the slow erosion of parts of Enza Zaden's land.
The managers of Enza Zaden became increasingly frustrated with the conflict situation. In addition to the harm being done to their land by trespassing villagers, the noise from the occasional brawl would wake up the manager and his family whose house is located near to the furrow intake. The manager of Enza Zaden met with representatives from each side and proposed that the intake point itself be moved farther downstream, away from the estate house. In addition, Enza Zaden proposed to fund the construction of an intake weir. A second meeting was held with water representatives from Manyire, Nambala, Kikwe, and Maweni in attendance. The estate's production manager facilitated the meeting. The previously agreed upon irrigation schedule was modified, put into a written contract, and signed on an Enza Zaden official letterhead. While prior to the agreement Nambala, Kikwe, and Maweni received water from 2 am to $3 \mathrm{pm}$, the current (dry season) schedule has reduced their allocation to the period between 6 am and $3 \mathrm{pm}$. On the part of Enza Zaden, the company agreed to finance the construction of a permanent intake structure.

According to Enza Zaden's seed-cleaning manager, the villagers have so far stuck to the agreed furrow schedule; there have been no recent violent disputes over accusations of 'intake gate' tampering. Throughout this process Enza Zaden made no attempt to contact any level of the local government or PBWO, though both Manyire and Nambala claimed to have requested intervention of the district commissioner without response. When asked what the purpose of signing the contract was, both parties replied similarly. The villagers think that it affords them some 'evidence of agreement' against the other, though a local court is unlikely to consider this informal document binding. A member of the Manyire River Committee and resident of Manyire Village, claims that during a particularly heated encounter with Nambala furrow guards, he threatened to go to the police 'with the signed document in hand.' In response to this threat the men backed down. Villagers of Nambala, when asked for comment on the above anecdote explained that they understood that the document offered no real power of enforcement, 'just the power of everyone signing.' In return for its mediation role, Enza Zaden is treated like a relative by the villagers and many downstream farmers feel comfortable with the estate.

\section{Negotiated allocation: Estates' agreeing with the local River Committee}

During the rainy season (March to May and November to December) the villagers only use furrows for supplemental irrigation, but they engage in full-scale irrigation during the dry season. The estates are able to meet their full irrigation demands during rainy seasons and high flows. However, during the dry seasons, the Nduruma River Committee demands that all estates must reduce the time of their abstraction and the duration is negotiated every month. Most of the estates are active participants in the negotiation process and have representatives who attend every meeting. These estates include Arusha Blooms, Kiliflora, Tanzania Flowers, Dekker Bruins and Old River estates. The estates often contribute small amounts of financial support for drinks and transportation of members of the River Committees. Dekker Bruins particularly has invested in a strong relationship with the River Committee: all monthly meetings are held on the property of the estate and for each meeting Dekker provides refreshments for the participants. The estate's farm manager attributes this support to a necessity of cooperation. At the start of our research 
(January 2009), the arrangement stipulated that the estates and the village of Mlangarini abstracted water from 6 am to $4 \mathrm{pm}$. At $4 \mathrm{pm}$ their gates are closed and the water is allowed to flow downstream into the open furrows of Nduruma Village and the other users below the Maruroi furrow. This rotational agreement was revised in February 2009 and estates' schedule was from 5 am to $1 \mathrm{pm}$. To enforce this, the River Committee employs a water guard who patrols along the river, checking each and every intake of the large-scale irrigators. According to the Director of Arusha Blooms, the agreement with the River Committee during the dry season means that they don't get enough water and the estates are forced to skip some irrigation schedules, which translate to an estimated $10 \%$ loss in production. She stated that, over time, the problem is not water volume per se, but the lack of storage facility at the estate to maintain production during the dry season. The estates also negotiate between themselves. Arusha Blooms reported that they often send their representative (a Tanzanian national) to request additional time from the other estates and at times from the River Committee. The estate managers typically prefer to settle water concerns in this informal fashion without resorting to any outside authority (e.g., PBWO). Estates see their cooperative agreement with the downstream smallholder farmers as an act of good neighbourliness, although they also admit to trying to address complaints that could tarnish the companies' image internationally. The manager of Dekker Bruins stated explicitly during our interview, that to acquire a certification from The Netherlands they must be seen as working with the local communities. The manager of Tanzania Flowers stated that because one of its farms is located on the boundary between the largescale irrigators and downstream smallholder farmers, they find themselves much more involved in the River Committee's activities, while the other estates further upstream interact very little with the Board. The estates argue that their participation is an attempt to make downstream users understand that water use by the estate also generates benefits for the community downstream (e.g., employment opportunity, as well as schools and dispensaries constructed through their social responsibility projects).

However, the agreement is not without controversy. Some of the estates do not strictly abide by the River Committee's decision on water allocation, and Kiliflora is one such estate. Kiliflora uses an electric pump to convey water directly from the river to its reservoirs instead of employing the traditional gravity-facilitated furrow method. Unlike the other foreignowned estates of similar size, Kiliflora irrigates using the relatively inefficient method of trough irrigation instead of drip. A trough is a U-shaped channel used to supply water and/ or nutrient solutions to potted plants. According to the estate's fertigation officer, they run 2 pumps simultaneously, 6-8 hours a day, 7 days a week, between 5 am and $1 \mathrm{pm}$. There are also 2 reservoirs located on the farms with storage capacities of $65000 \mathrm{~m}^{3}$ and $3000 \mathrm{~m}^{3}$. Also in this case the Nduruma River Committee determines the hours when Kiliflora is allowed to operate its pumps - during the dry season of January 2009 its allocation had just been reduced by an hour. Kiliflora's pumps are a matter of concern amongst the member of the River Committee and the downstream villagers whom they represent. In the fertigation officer's words, 'We spent most of the last meeting negotiating over when we could operate our pumps. People from the village don't understand that we have a right to take this water.' Representatives of the Board reported that Kiliflora often runs its pumps outside of its permitted time window and the irrigation managers of Arusha Blooms and Dekker
Bruins corroborated this fact. However, the fertigation officer denies that Kiliflora has ever gone against the prescriptions of the Board. The fertigation officer however admitted that Kiliflora withdraws more water than its PBWO-granted water right allows. 'Sometimes we take more and sometimes we take less, in the dry season we take more than the water right grants.' He justifies this trespass by explaining, 'We do struggle with water...we struggle to maintain production during the dry season.' The efficacy of the Nduruma River Committee was reportedly tested when the water guards found Kiliflora operating its water pump at unsanctioned hours. Kiliflora, like all large-scale irrigators in the area, is surrounded by a high fence and employs a security guard at its gates. When the Board officials appeared at the estate to address this issue and collect the penalty, they weren't allowed in or granted an audience with the Kiliflora manager. Several letters explaining the infraction were ignored. The fertigation officer did not acknowledge that these events took place and insisted that his company follows the mandates of the Board.

It seems that, in general, the estates that participate in the Nduruma River Committee think that the organisation is necessary for the region and are satisfied with its operation. The irrigation managers acknowledge that in the dry season water in the Nduruma River is insufficient to meet all demands. Dekker Bruins' representative explains that it is much better to have a venue for people to discuss their needs and complaints than to resort to violence:

'There are more than 1000 people downstream that need this same water. We cannot fight with them. In the past there was no discussion - machetes were always brought out whenever there were problems, but now the downstream villages are trying to organise.'

A common complaint voiced by several of the large-scale irrigators is that there is a lack of continuous Board activity throughout the whole year. They feel that the Board is too concerned with matters of allocation and not concerned enough by longer-term issues, such as source maintenance.

\section{Discussion}

The Nduruma case illustrates the fact that sources of water rights are diverse, complex and often conflicting. It also highlights the issue that water rights do not arise solely from state laws, agencies and courts, but also from local institutions and views of other resource users. In Nduruma the question of legitimacy is at the centre of the water rights struggle. Water rights struggles in Nduruma conform to the 4 components of the water right analysis as proposed by Boelens (2008), but in a complex way. In this section we explore the dynamic of the Nduruma water right struggles. The order is for presentation only as the 4 components are involved simultaneously.

First, the competition over possession and use of resources in the sub-catchment dates back to colonial times. As described by Spear (1997), land ownership was a heavily contested matter by local Meru communities, colonial administration and European settlers throughout colonial times. The German and British colonists alienated land around the base of Mount Meru. The land and labour control struggle was only brought to a close when the Meru people protested and appealed to the United Nations against British seizure of more land (see Spear, 1997). The induced land inequities however still shape presentday struggles over who gets access to water; the competition is at its most intense between the large-scale irrigators (midland) 
and the downstream smallholder farmers. In their midland position, the estates are sandwiched between smallholders farmers who are located both upstream and downstream of the sub-catchment. Hence, the estates are both advantaged and disadvantaged in terms of hydraulic location.

At the second level is the contest over the content of water rights and its enforcement. Large-scale irrigators have location advantage over the downstream farmers, and from their international origin, they also have better access to other resources (e.g., knowledge, better irrigation technology and financial means). Estates also benefit from a close connection with a national government which is interested in encouraging foreign investment. The estates also claim water access based on state-issued water rights, which are labelled 'official' and therefore legitimate. Hence, in their midstream location, the estates may be considered more powerful. The estates' water allocation, especially during dry seasons, does not go unchallenged by the downstream smallholder farmers. These farmers demanded that allocation should be rotational and take into account supply variability and not absolute values specified in the government water right. Most estates in the midstream engage in negotiations with the smallholder farmers and tend to agree on a time-based allocation during scarcity even when this implies loss of production.

This research found that the most successful large-scale irrigators are those able to engage with local systems of negotiation and rotational water allocations. By adopting this strategy, the estates not only avoid conflict with the local farmers, but also gain social reputation in the area, increasing the chance of cooperation from the farmers towards their hydraulic infrastructure investments. The main reasons for negotiation, according to their representatives, are that it is:

- much better to have a venue for people to discuss and complain than to resort to violence;

- a matter of water security; and

- an organised front that can forcefully represent their interest at a larger scale (catchment-wide or to the Pangani Basin Water Office).

Their cooperation seems to fit the argument that the larger one's stake, the larger one's interest in the common good and thus the more responsibly one may act (Van der Zaag, 2007). Violent response by the smallholder farmers on estates' water infrastructure is sufficient incentive for the estates to cooperate and broker cooperative and equitable deals. This is illustrated by the case of Enza Zaden Estate stepping in to mediate water conflict between 2 villages. In return for its help, it gains respect of the villages. Gomba Estate, by contrast, provides a situation where non-cooperative behaviour led to self-destruction in the long run, as the estate was forced out of business with lack of water being a major factor.

At the third level, regulatory control, the paper has shown that this power is largely exercised by the Nduruma River Committee, which claims to have legitimate decision-making authority and takes responsibility for allocating water between midland and lowland farmers. This cooperative arrangement seems to only work well between close neighbours; at larger spatial distance it is less effective. The major weakness of the Nduruma River Committee is that its membership only encompasses large-scale irrigators and the downstream users. The Board is simply managing water the upstream villages were unable to use. Since highland farmers do not have river committees, it is difficult for the Nduruma River Committee to engage with them.
The fourth level, dealing with regime of representation is best described by the water management perspectives of the different levels of government. The national government is interested in enforcing statutory water policies, laws and hierarchies, as well as promoting foreign commercial investment. However, the local district administrations are more likely to spend their limited resources 'keeping the peace', rather than enforcing the letter of the water law. Estates that refuse to cooperate with smallholder farmers are often told by district administrators to go back and negotiate with their neighbours.

\section{Conclusions}

This paper has described how water access is negotiated between smallholder irrigators and large-scale irrigators sharing the water of Nduruma River, Upper Pangani River Basin, Tanzania. The spatial geography of Nduruma is such that smallholder farmers are located upstream and downstream, while large-scale irrigators are in the midstream part of the sub-catchment. There is not enough water in the river to satisfy all demands. The majority of the smallholder farmers currently access water under local arrangements, while large-scale irrigators have obtained state-issued water use permits.

Although in such a context one would expect the weaker downstream farmers to lose out, instead cooperation prevails. Smallholder farmers in the sub-catchment counter inequities in land and water distribution by enforcing suitable allocation proxies (proportional division, time-based turns) which make water rights more meaningful. Powerful estates that do not agree to the terms of the local agreements find it difficult to keep on operating, as their water infrastructure may be vandalised by smallholder irrigators. In addition, local government officials pay little attention to the pleas by estates, thereby leaving the smallholder farmers with sufficient autonomy (see also: Schlager and Ostrom, 1992).

The case study shows that a River Committee, an institution that was locally established and engineered and that is not formally recognised in statute law in Tanzania, has been conducive in structuring water allocation in a manner that has been effective and that has forestalled major conflicts. The institutional form of a River Committee has thus bridged local rules and statute law with respect to water.

We find the most successful estates are those able to cooperate with the smallholder farmers. The risk of the estates to lose a lot is here sufficient incentive for them to cooperate and broker cooperative and equitable deals with their less powerful counterparts (cf. Baland and Platteau, 1999). In such a situation it becomes less easy for the many small water users to defect. But cooperative behaviour by the estates may also be due to other interdependencies between them and the smallholder farmers. Large-scale irrigators have to engage with their downstream villages because of their dependence on local labour. In addition, cooperation with smallholder farmers helps reinforce the water claim of the estates at larger spatial scales. However, this case study also shows that at the larger catchment scale it has so far been impossible to institute and maintain effective cooperative arrangements, despite the formally established structures.

\section{Acknowledgements}

The work reported here was undertaken as part of the Smallholder System Innovations in Integrated Watershed Management (SSI) Programme funded by the Netherlands 
Foundation for the Advancement of Tropical Research (WOTRO), the Swedish International Development Cooperation Agency (Sida), the Netherlands Directorate-General of Development Cooperation (DGIS), the International Water Management Institute (IWMI) and UNESCO-IHE Institute for Water Education. We acknowledge the support of SNV Arusha staff, Pangani Basin Water Office Moshi, and thank Ms Angelina Christian and Mr. Raymond Mokiwa for their translation services, and appreciate the time of the water users' communities, villages, wards and districts we worked with during the research. We thank the 2 anonymous reviewers and the editor of Water $S A$ for their comments and suggestions.

\section{References}

BAFFES J (2003) Tanzania's coffee sector: constraints and challenges in a global environment. in, World Bank, Washington DC.

BALAND J-M and PLATTEAU J-P (1999) The ambiguous impact of inequality on local resource management. World Dev. 27 (5) 773-788.

BODANSKY DM (1999) The legitimacy of international governance: a coming challenge for international environmental law? Am. J. Int Law 93 (3) 596-624.

BODANSKY DM (2007) The concept of legitimacy in international law. In Research paper series, University of Georgia School of Law, pp. 1-8.

BOELENS R (2008) Water rights arenas in the Andes: upscaling networks to strengthen local water control. Water Alternatives 1 (1) 48-65.

BROMLEY DW (1997) Constitutional political economy: property claims in a dynamic world. Contemp. Econ. Polic. 15 (4) 43-54.

BRUNS B (2007) Irrigation water rights: options for pro-poor reform. Irrig. Drain. 56 (2-3) 237-246.

BRUNS BR and MEINZEN-DICK RS (2001) Water rights and legal pluralism: four contexts for negotiation. Nat. Resour. Forum 25 (1) $1-10$.

COWARD EWJ (1986) Direct or indirect alternatives for irrigation investment and the creation of property. In: Easter KWS (ed.) Irrigation Investment, Technology and Management Strategies for Development. Westview Press, Boulder.

GEAREY M and JEFFREY P (2006) Concepts of legitimacy within the context of adaptive water management strategies. Ecol. Econ. 60 (1) 129-137.

KOMAKECH HC and VAN DER ZAAG P (2010) Conflicts and contradictions over the allocation of scarce water: cities versus subsistence irrigation in the Pangani river basin, Tanzania. Paper presented at the 11th WaterNet/WARFSA/GWP-SA Symposium
"IWRM: for national and regional integration - where science, policy and practice meet”, 27-29 October, Victoria Falls.

KOMAKECH HC, VAN KOPPEN B, MAHOO HF and VAN DER ZAAG P (2011) Pangani river basin over time and space: on the interface of local and basin level responses. Agric. Water Manage. 98 (11) 1740-1751.

LANKFORD B and BEALE T (2007) Equilibrium and non-equilibrium theories of sustainable water resources management: Dynamic river basin and irrigation behaviour in Tanzania. Global Environ. Change 17 (2) 168-180.

LEIN H and TAGSETH M (2009) Tanzanian water policy reforms between principles and practical applications. Water Polic. 11 (2) 203-220.

MAGANGA FP (2003) Incorporating customary laws in implementation of IWRM: some insights from Rufiji River Basin, Tanzania. Phys. Chem. Earth 28 995-1000.

MEHTA L (2007) Whose scarcity? Whose property? The case of water in western India. Land Use Polic. 24 (4) 654-663.

MOLLE F (2004) Defining water rights: by prescription or negotiation? Water Polic. 6 207-227.

PICCIONE M and RAZIN R (2009) Coalition formation under power relations. Theor. Econ. 4 (1) 1-15.

SCHLAGER E and OSTROM E (1992) Property-rights regimes and natural resources: a conceptual analysis. Land Econ. 68 (3) 249-262.

SHI T (2006) Simplifying complexity: Rationalizing water entitlements in the southern connected river Murray system, Australia. Agric. Water Manage. 86 229-239.

SPEAR T (1997) Mountain Farmers: Moral Economies of Land and Agricultural Development in Arusha and Meru. James Currey, Oxford. 262 pp.

UNITED REPUBLIC OF TANZANIA (2002) National Water Policy. Ministry of Water and Livestock Development, Dar es Salaam, Tanzania.

UNITED REPUBLIC OF TANZANIA (2009) The Water Resources Management Act Supplement No. 11. Government Printer, Dar es Salaam. 353-424.

VAN DER ZAAG P (2007) Asymmetry and equity in water resources management; critical institutional issues for Southern Africa. Water Resourc. Manage. 21 (12) 1993-2004.

VAN KOPPEN B, SOKILE CS, LANKFORD B, HATIBU N, MAHOO HF and YANDA PZ (2007) Water rights and water fees in rural Tanzania. Chapter 6. In: Molle F and Berkoffs J (eds.) Irrigation Water Pricing - The Gap between Theory and Practice. CAB International, Wallingford. 143-164.

ZWARTEVEEN M, ROTH D and BOELENS R (2005) Water rights and legal pluralism: beyond analysis and recognition. Chapter 12. In: Roth D, Boelens R and Zwarteveen M (eds.) Liquid Relations. Contested Water Rights and Legal Complexity. Rutgers University Press, New Brunswick, NJ 254-268. 
http://dx.doi.org/10.4314/wsa.v38i1.14 Available on website http://www.wrc.org.za

ISSN 0378-4738 (Print) = Water SA Vol. 38 No. 1 January 2012 ISSN 1816-7950 (On-line) = Water SA Vol. 38 No. 1 January 2012 